\title{
Insulin-releasing and insulin-like activity of the traditional anti-diabetic plant Coriandrum sativum (coriander)
}

\author{
Alison M. Gray* and Peter R. Flatt \\ School of Biomedical Sciences, University of Ulster, Coleraine BT52 1SA, UK
}

(Received 3 April 1998 - Revised 5 October 1998 - Accepted 8 October 1998)

\begin{abstract}
Coriandrum sativum (coriander) has been documented as a traditional treatment of diabetes. In the present study, coriander incorporated into the diet $(62.5 \mathrm{~g} / \mathrm{kg})$ and drinking water $(2.5 \mathrm{~g} / \mathrm{l}$, prepared by $15 \mathrm{~min}$ decoction) reduced hyperglycaemia of streptozotocin-diabetic mice. An aqueous extract of coriander $(1 \mathrm{mg} / \mathrm{ml})$ increased 2-deoxyglucose transport (1.6-fold), glucose oxidation (1.4-fold) and incorporation of glucose into glycogen (1.7-fold) of isolated murine abdominal muscle comparable with $10^{-8} \mathrm{M}$-insulin. In acute $20 \mathrm{~min}$ tests, $0 \cdot 25-10 \mathrm{mg} / \mathrm{ml}$ aqueous extract of coriander evoked a stepwise 1.3-5.7-fold stimulation of insulin secretion from a clonal B-cell line. This effect was abolished by $0.5 \mathrm{~mm}$-diazoxide and prior exposure to extract did not alter subsequent stimulation of insulin secretion by $10 \mathrm{mM}$-L-alanine, thereby negating an effect due to detrimental cell damage. The effect of extract was potentiated by $16.7 \mathrm{mM}$-glucose and $10 \mathrm{mM}-\mathrm{L}-\mathrm{alanine}$ but not by $1 \mathrm{mM}-3$-isobutyl-1-methylxanthine. Insulin secretion by hyperpolarized B-cells $(16.7 \mathrm{mM}$-glucose, $25 \mathrm{mM}-\mathrm{KCl})$ was further enhanced by the presence of extract. Activity of the extract was found to be heat stable, acetone soluble and unaltered by overnight exposure to acid $(0 \cdot 1 \mathrm{M}-\mathrm{HCl})$ or dialysis to remove components with molecular mass $<2000 \mathrm{Da}$. Activity was reduced by overnight exposure to alkali $(0 \cdot 1 \mathrm{M}-\mathrm{NaOH})$. Sequential extraction with solvents revealed insulin-releasing activity in hexane and water fractions indicating a possible cumulative effect of more than one extract constituent. These results demonstrate the presence of antihyperglycaemic, insulin-releasing and insulin-like activity in Coriandrum sativum.
\end{abstract}

\section{Coriander: Insulin: Diabetes mellitus}

Before the discovery of insulin in the early 1920s and the later development of oral hypoglycaemic agents, the major form of treatment of diabetes mellitus involved starvation, dietary manipulation and the use of plant therapies (Bailey \& Flatt, 1990). More than 400 plants worldwide have been documented as beneficial in the treatment of diabetes (Bailey \& Day, 1989; Swanston-Flatt et al. 1991; Gray \& Flatt, 1997a). However, most of these await proper scientific or medical evaluation, and the World Health Organization (1980) has recommended accordingly that assessment of traditional plant treatments for diabetes merits further investigation.

Coriandrum sativum (coriander) has been reported to have a number of possible medicinal attributes including antispasmodic, carminitive and stomachic properties (Lust, 1986). Additionally, coriander has been advocated as an anti-diabetic remedy (Farnsworth \& Segelman, 1971; Lewis \& Elvin-Lewis, 1977). More recent studies have confirmed the antihyperglycaemic effect of coriander in streptozotocin-diabetic mice (Swanston-Flatt et al. 1990), suggesting that further studies are warranted on the antihyperglycaemic actions of this plant. Anti-diabetic agents can exert beneficial effects in the diabetic environment by improving and/ or mimicking insulin action and/or by enhancing insulin secretion (Gray \& Flatt, 1997b). To understand better the mechanisms by which coriander ameliorates hyperglycaemia, the present study investigated in vitro actions of aqueous extracts of coriander on glucose metabolism by isolated murine abdominal muscle and on insulin secretion by a clonal B-cell line (BRIN-BD11).

\section{Materials and methods \\ Plant material}

Dried coriander seeds were obtained from a commercial source in Birmingham, West Midlands, UK. Seeds were homogenized to a fine powder and stored at room temperature $\left(20 \pm 2^{\circ}\right)$ in opaque screw-top jars. Powdered coriander was used for incorporation into test animal diet. An aqueous

\footnotetext{
Abbreviations: KRB, Krebs-Ringer bicarbonate buffer; STZ, streptozotocin.

* Corresponding author: Dr Alison Gray, present address: Young Hearts Project, Level 3 McKinney House, Musgrave Park Hospital, Belfast BT9 7JB, UK, fax +44 (0) 1232 382008, email youngheartsproject@hpsspop.n-i.nhs.uk
} 
extract of coriander was prepared by a method of decoction as described previously (Gray \& Flatt, 1998a). In brief, $1 \mathrm{~g}$ powdered material was placed in $40 \mathrm{ml}$ cold (distilled) water, brought to the boil, then removed from the heat source and allowed to infuse for $15 \mathrm{~min}$. This suspension was filtered (Whatman no. 1) and the volume readjusted to $40 \mathrm{ml}$ with distilled water. For in vivo studies $10 \mathrm{ml}$ portions of extract were stored at $-20^{\circ}$ until use when they were diluted tenfold with tap water $(2 \cdot 5 \mathrm{~g} / \mathrm{l})$. For in vitro studies $1 \mathrm{ml}$ portions of extract were brought to dryness under vacuum (Savant speedvac; Savant Instrumentation Incorp., Framingdale, NY, USA), stored at $-20^{\circ}$ and reconstituted on the day of use with incubation buffer. Incubations within a single experiment using isolated muscle or BRIN-BD11 cells were always conducted using the same batch of extract. This allowed for any variation in potency of different batches of extract.

\section{Animal studies}

Heterozygous lean $(o b /+)$ male mice derived from a colony maintained at Aston University, Birmingham, UK (Flatt \& Bailey, 1981) were used at 21-24 weeks of age. Groups of two or three mice were housed in an air-conditioned room at $22 \pm 2^{\circ}$ with a lighting schedule of $12 \mathrm{~h}$ light (08.00-20.00 hours) and $12 \mathrm{~h}$ dark. Animals had free access to a standard pellet diet (Mouse Breeding Diet, Pillsbury Ltd, Birmingham, W. Midlands, UK) and tap water. The overall nutrient composition of the diet was $(\mathrm{g} / \mathrm{kg})$ : carbohydrate 362 , protein 209 , fat 44 and fibre 385 with a metabolizable energy content of $11.8 \mathrm{MJ} / \mathrm{kg}$. The experimental procedure for in vivo studies was similar to that previously described (Gray \& Flatt, 1997b). For animal diets, coriander was incorporated into powdered mouse diet and mixed thoroughly, then distilled water was added and the mixture was combined to a stiff paste. The diet was then pelleted and placed at $45^{\circ}$ until dry. Control diet was prepared by the same method to ensure there were no end differences in vitamin and mineral content as a result of the drying process. Coriander was incorporated into the diet $(62.5 \mathrm{~g} / \mathrm{kg})$ and drinking water $(2.5 \mathrm{~g} / \mathrm{l})$ of a group of seven mice $5 \mathrm{~d}$ before and after intraperitoneal administration of streptozotocin (STZ; Sigma Chemical Co., Poole, Dorset, UK) at $200 \mathrm{mg} / \mathrm{kg}$ body weight in $0.1 \mathrm{M}-$ sodium citrate buffer ( $\mathrm{pH} 4.5)$. Daily measures of body weight, food intake and fluid intake were made. Non-fasting blood samples obtained from the cut tail-tip of conscious mice were collected at the same time (09.00-10.00 hours) for plasma glucose analysis (Stevens, 1971). Groups of six normal mice and six STZ-treated mice with free access to unsupplemented diet and drinking water were used as controls.

\section{Glucose transport and glucose metabolism in vitro}

Recently-weaned non-fasting male mice (3-5 weeks) were killed by cervical dislocation and pieces of abdominal muscle (approximately $10-20 \mathrm{mg}$ ) were prepared. In order to replicate by mouse, pieces of muscle from each mouse were designated to each of the treatment groups. Glucose uptake was determined as described previously (Gray \&
Flatt, 1998b). In brief, muscle pieces were incubated at $30^{\circ}$ for $30 \mathrm{~min}$ in Krebs-Ringer bicarbonate buffer (KRB) supplemented with $2 \mathrm{mM}$-sodium pyruvate, $3.70 \mathrm{kBq} / \mathrm{ml} \mathrm{2-}$ deoxy-D- $\left[1-{ }^{3} \mathrm{H}\right]$ glucose, $0 \cdot 37 \mathrm{kBq} / \mathrm{ml} \mathrm{L-}\left[1-{ }^{14} \mathrm{C}\right]$ glucose in the presence and absence of $10^{-8} \mathrm{M}$-human insulin and $1 \mathrm{mg} / \mathrm{ml}$ extract of coriander $(2 \times 2$ factorial design $)$. Oxidative glucose metabolism to $\mathrm{CO}_{2}$ and incorporation of glucose into glycogen were determined as described previously (Gray \& Flatt, 1998b). In brief, muscles were incubated at $37^{\circ}$ for $60 \mathrm{~min}$ in KRB supplemented with $10 \mathrm{mM}$-glucose, $18.50 \mathrm{kBq} / \mathrm{ml} \mathrm{D}-\left[\mathrm{U}-{ }^{14} \mathrm{C}\right]$ glucose in the presence and absence of $10^{-8} \mathrm{M}$-human insulin and $1 \mathrm{mg} / \mathrm{ml}$ extract of coriander $(2 \times 2$ factorial design). Following incubation, $\mathrm{CO}_{2}$ was captured onto a $\mathrm{NaOH}$-saturated filter paper and muscles were removed for glycogen analysis (Gray \& Flatt, 1998b).

\section{Insulin secretion in vitro}

BRIN-BD11 cells, produced by electrofusion of immortal RINm5F cell with New England Deaconess Hospital rat pancreatic B-cell, were used to evaluate insulin secretion (McClenaghan et al. 1996; Gray \& Flatt, 1997b). In brief, wells containing $0.2 \times 10^{6}$ insulin-secreting cells were washed with KRB containing $1.1 \mathrm{mM}$-glucose and preincubated for $40 \mathrm{~min}$ at $37^{\circ}$ (Gray \& Flatt, 1997b). Unless otherwise stated, cells were then incubated for $20 \mathrm{~min}$ with $\mathrm{KRB}$ at $1.1 \mathrm{mM}$-glucose in the absence and presence of plant extract, diazoxide (an established opener of $\mathrm{K}^{+}$ATP channels) and other test agents. Following incubation, portions were removed from each well and stored at $-20^{\circ}$ for insulin assay (Flatt \& Bailey, 1981). Modified neutral red assay (Hunt et al. 1987) confirmed that $0 \cdot 25-10 \mathrm{mg} / \mathrm{ml}$ coriander extract did not influence the viability of BRINBD11 cells during the test period.

To assess the importance of heat during extract preparation, aqueous extracts of coriander were prepared by the normal method of decoction (normal extract) or by cold infusion (cold extract; plant material placed in cold water, allowed to stand for $15 \mathrm{~min}$, then filtered as before). Modified aqueous extract was freshly reconstituted in KRB and the effect on insulin secretion evaluated at a concentration equivalent to $1 \mathrm{mg} / \mathrm{ml}$ compared with normal extract (produced by $15 \mathrm{~min}$ decoction, as described previously). To further evaluate the nature of the insulin-releasing component(s), the normal aqueous extract of coriander prepared by decoction was subjected to heat, overnight dialysis, acidalkali or acetone treatment. Heat: aqueous extract was boiled for $1 \mathrm{~h}$ immediately after preparation. Dialysis: aqueous extract was dialysed overnight (Spectra/Por molecular mass cut-off $2000 \mathrm{Da}$; Spectrum, Los Angeles, CA, USA) against deionized water (Milli-Q, Millipore Corp., Milford, MA, USA) at $4^{\circ}$. Acid-alkali treatment: portions of aqueous extract were added to $5 \mathrm{M}-\mathrm{HCl}$ or $5 \mathrm{M}-\mathrm{NaOH}$ to produce $0 \cdot 1 \mathrm{M}-\mathrm{HCl}$ or $0 \cdot 1 \mathrm{M}-\mathrm{NaOH}$, allowed to stand at room temperature overnight, then neutralized. Acetone treatment: $1 \mathrm{ml}$ aqueous extract $(1 \mathrm{mg} / \mathrm{ml})$ was added to $10 \mathrm{ml}$ ice-cold acetone, allowed to stand for $30 \mathrm{~min}$ (on ice) and centrifuged (1000 rev./min; $5 \mathrm{~min}$ ) to obtain acetone-soluble and acetoneinsoluble fractions. Portions of untreated extract and modified aqueous extracts were dried under vacuum. All modified 
aqueous extracts were freshly reconstituted in KRB and effects on insulin secretion at a concentration equivalent to $1 \mathrm{mg} / \mathrm{ml}$ were compared with that of untreated extract.

In another series of experiments ground coriander seeds were subjected to sequential extraction by increasingly polar solvents. Plant material $(0.25 \mathrm{~g})$ was placed in $5 \mathrm{ml}$ hexane, agitated for $15 \mathrm{~min}$ and centrifuged (1200 rev./min; $5 \mathrm{~min}$ ). The precipitate was dried under vacuum, extracted with a further $5 \mathrm{ml}$ hexane and centrifuged as before. The extraction supernatant fractions were pooled, filtered (Whatman no. 1) and the volume adjusted to $10 \mathrm{ml}$ hexane. The extraction precipitate (dried under vacuum) was subsequently extracted (as described earlier) with two $5 \mathrm{ml}$ volumes of ethyl acetate, then methanol and finally with water. All extract fractions were brought to dryness under vacuum and freshly reconstituted in KRB for investigation of effects on insulin secretion at a concentration equivalent to $1 \mathrm{mg} / \mathrm{ml}$ compared with untreated extract.

\section{Statistical analyses}

Data were evaluated using Student's unpaired $t$ test, oneway ANOVA or two-way ANOVA where appropriate. Groups were considered to be significantly different if $P$ $<0.05$. When a significant $F$ value was obtained for ANOVA the differences between all pairs were tested using the Student-Newman-Keuls multiple comparisons test. If standard deviations were significantly different (Bartlett's test for homogeneity of variances) data were transformed $\left(\log _{10}[\mathrm{x}]\right)$.

\section{Results}

\section{Studies in vivo}

Compared with normal mice, STZ-treated mice showed significant $(P<0.05)$ weight loss, polydipsia and hyperglycaemia (Table 1). Administration of coriander in the diet and drinking water significantly decreased the hyperglycaemia by study day 20 (Table 1). Polydipsia increased in coriander supplemented $v$. unsupplemented STZ-treated mice (Table 1) and may indicate the presence of diuretic components in coriander seed. Plasma glucose concentrations of STZ-treated mice receiving coriander were comparable to those of normal mice at day 20 (Table 1). Throughout the study levels of food intake by treatment groups did not differ.

\section{Glucose transport and glucose metabolism in vitro}

Aqueous extract of coriander $(1 \mathrm{mg} / \mathrm{ml})$ increased glucose uptake (1.6-fold), glucose oxidation (1.4-fold), and glycogenesis (1.7-fold) during incubations without insulin but did not significantly alter the stimulatory effect of $10^{-8} \mathrm{M}$ insulin (Table 2).

\section{Insulin secretion in vitro}

Aqueous extract of coriander $(0 \cdot 25-10 \mathrm{mg} / \mathrm{ml})$ had a dosedependent $1 \cdot 3-5 \cdot 7$-fold stimulatory effect on insulin secretion by BRIN-BD11 cells at $1.1 \mathrm{~mm}$-glucose (Fig. 1). It was confirmed that these concentrations of extract did not influence the viability of BRIN-BD11 cells during the test period as evaluated by modified neutral red assay (Hunt $e t$

Table 1. Effects of coriander, administered in the diet $(62.5 \mathrm{~g} / \mathrm{kg})$ and drinking water $(2.5 \mathrm{~g} / \mathrm{l})$ on body weight, fluid intake, food intake and plasma glucose concentrations of streptozotocin (STZ)-treated miceł

(Mean values with their standard errors for six or seven mice)

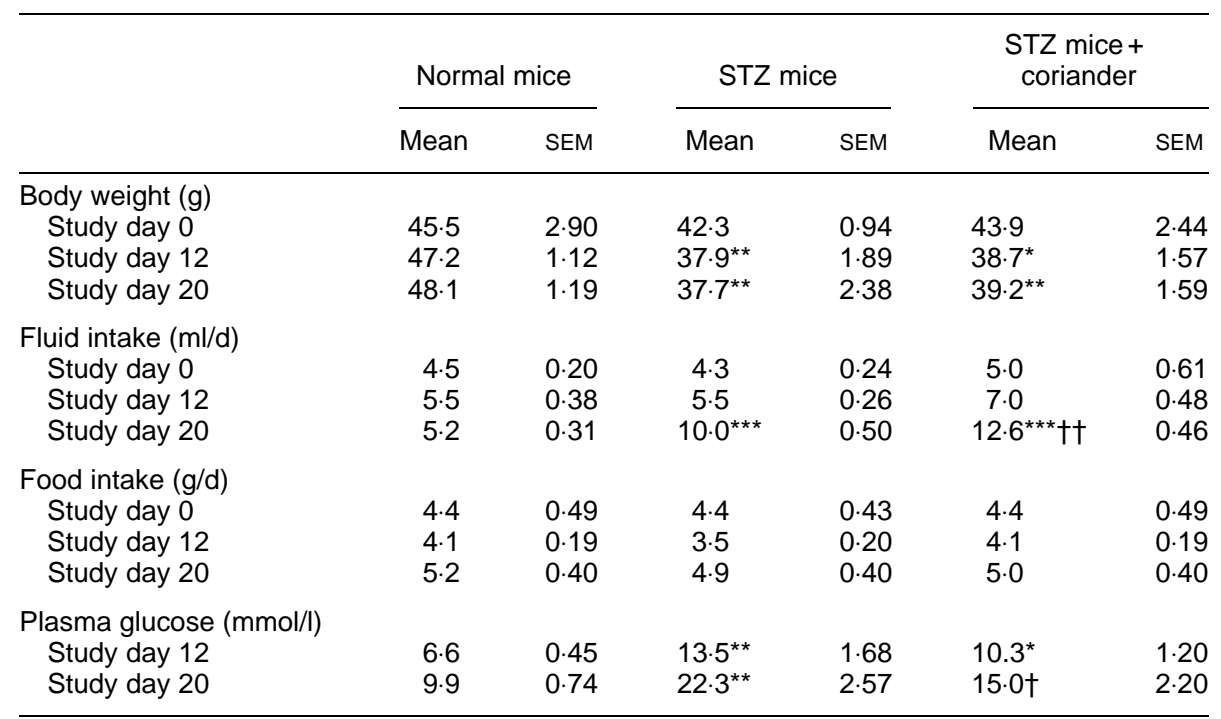

Mean values were significantly different from those for normal mice: ${ }^{\star} P<0.05,{ }^{\star \star} P<0.01$, ${ }^{\star \star \star} P<0.001$.

Mean values were significantly different from those for STZ-treated mice receiving normal diet: $\dagger P<0.05$, $\dagger \dagger P<0.01$

¥ For details of diets and procedures, see pp. 203-205. STZ was administered $4 \mathrm{~d}$ after the introduction of coriander (day 0). 
Table 2. Glucose uptake, oxidation and incorporation into glycogen by isolated mouse abdomen muscle incubated with aqueous extract of coriander in the presence or absence of $10^{-8} \mathrm{M}$-insulin

(Mean values with their standard errors for six or eleven samples)

\begin{tabular}{|c|c|c|c|c|c|c|c|c|}
\hline & \multicolumn{2}{|c|}{ Control } & \multicolumn{2}{|c|}{$\begin{array}{c}\text { Insulin } \\
\left(10^{-8} \mathrm{M}\right)\end{array}$} & \multicolumn{2}{|c|}{$\begin{array}{c}\text { Extract } \\
(1 \mathrm{mg} / \mathrm{ml})\end{array}$} & \multicolumn{2}{|c|}{$\begin{array}{c}\text { Insulin + } \\
\text { extract }\end{array}$} \\
\hline & Mean & SEM & Mean & SEM & Mean & SEM & Mean & SEM \\
\hline Glucose oxidation (nmol/mg per h) $(n 11)$ & 0.44 & 0.05 & $0 \cdot 70^{*}$ & 0.04 & $0.63^{\star * *}$ & 0.05 & $0 \cdot 76^{\star * *}$ & 0.05 \\
\hline Incorporation of glucose into glycogen (nmol/mg per h) $(n 11)$ & 0.23 & 0.03 & $0.47^{*}$ & 0.09 & $0.39^{*}$ & 0.06 & $0.42^{\star *}$ & 0.06 \\
\hline
\end{tabular}

Mean values were significantly different from those for control incubations: ${ }^{\star} P<0.05,{ }^{\star \star} P<0.01,{ }^{\star \star \star} P<0.001$.

al. 1987). The presence of $0.5 \mathrm{mM}$-diazoxide inhibited the stimulatory effect of the extract (Fig. 2(a)), indicating that the enhancement of insulin release was not a mere consequence of cellular damage. Consistent with this view, prior exposure of BRIN-BD11 cells to extract for $20 \mathrm{~min}$ did not alter the subsequent insulin secretory response to $10 \mathrm{mM}-\mathrm{L}-$ alanine (Fig. 2(b)). The insulin-releasing effect of $1 \mathrm{mg} / \mathrm{ml}$ extract was markedly potentiated by the presence of high (16.7 mM) glucose (Fig. 3(a)) and by the presence of $10 \mathrm{mM}-$ L-alanine (Fig. 3(b)). However, the action of extract $(1 \mathrm{mg} / \mathrm{ml})$ was not potentiated by $1 \mathrm{mM}-3$-isobutyl-1-methylxanthine, which increases cyclic AMP in insulin-secreting cells (Sharp, 1979) (Fig. 3(c)). In contrast, aqueous extract of coriander further enhanced the insulin release by depolarized BRIN-BD11 cells (16.7 mM-glucose, $25 \mathrm{mM}-\mathrm{KCl}$ ) (Fig. 3(d)).

Temperature of extraction did not alter the effect of the extract in enhancing insulin secretion (results not shown). Prolonged exposure to heat, overnight dialysis or exposure to acid did not significantly alter the insulin-releasing effect

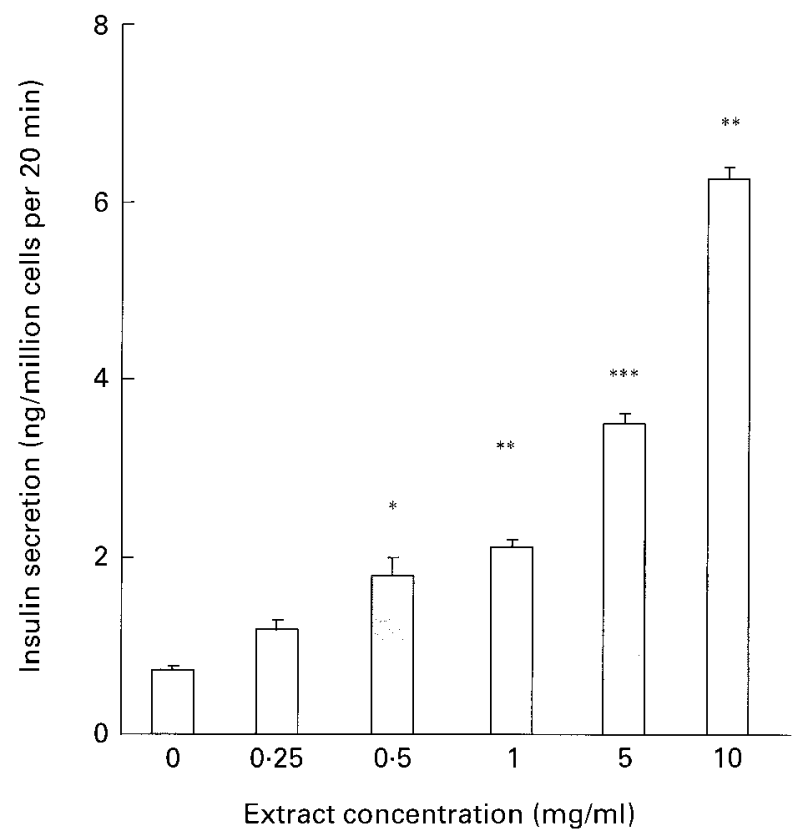

Fig. 1. Effects of aqueous extract of coriander on insulin secretion by BRIN-BD11 cells. Values are means for groups of four to six observations with their standard errors indicated by vertical bars. Mean values were significantly different from those for control incubations: ${ }^{*} P<$ $0.05,{ }^{*} P<0.01,{ }^{* \star *} P<0.001$. of the plant extract (Table 3). Prolonged exposure to an alkaline environment reduced the insulin-enhancing effect (Table 3). The insulin-releasing activity was completely retained in the acetone-soluble fraction (Table 3). Both the hexane and water fractions of coriander (produced by sequential extraction) exerted an insulin-enhancing effect comparable with normal aqueous extract of coriander (Fig. 4). Although less potent than the normal aqueous extract, the ethyl acetate and methanol fractions of coriander (produced by sequential extraction) exerted insulin-releasing effects (Fig. 4).

\section{Discussion}

Early experiments involving administration of coriander fruit as a decoction did not reveal effects on fasting blood

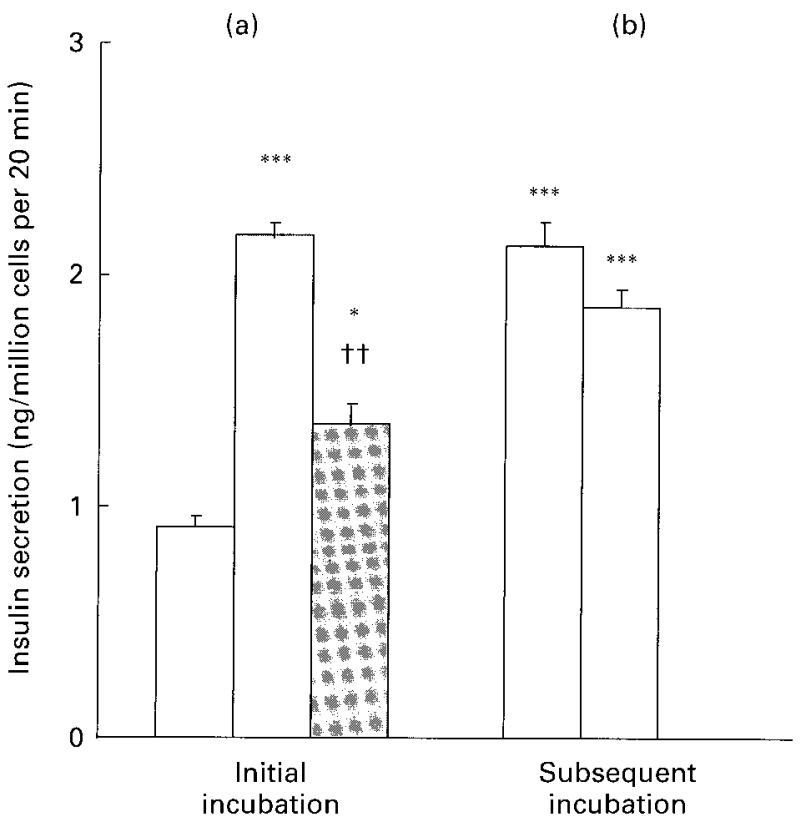

Fig. 2. (a) Insulin secretion by BRIN-BD11 cells in response to $1.1 \mathrm{~mm}$-glucose ( $\square$, control) and $1.1 \mathrm{~mm}$-glucose plus aqueous extract of coriander $(0.5 \mathrm{mg} / \mathrm{ml})$ in the absence $(\square)$ or presence $(\mathbf{\square})$ of $0.5 \mathrm{~mm}$-diazoxide. (b) Insulin secretion by BRIN-BD11 cells in response to $10 \mathrm{mM}$-L-alanine after $20 \mathrm{~min}$ prior exposure to $1.1 \mathrm{mM}$ glucose $(\square$, control) or coriander extract $(0.5 \mathrm{mg} / \mathrm{ml})(\square)$. Values are means for groups of six observations with their standard errors indicated by vertical bars. Mean values were significantly different from those for control incubations: ${ }^{*} P<0.05,{ }^{\star * \star} P<0.001$. Mean values were significantly different from those for incubation with extract: $\dagger \uparrow P<0.01$. 

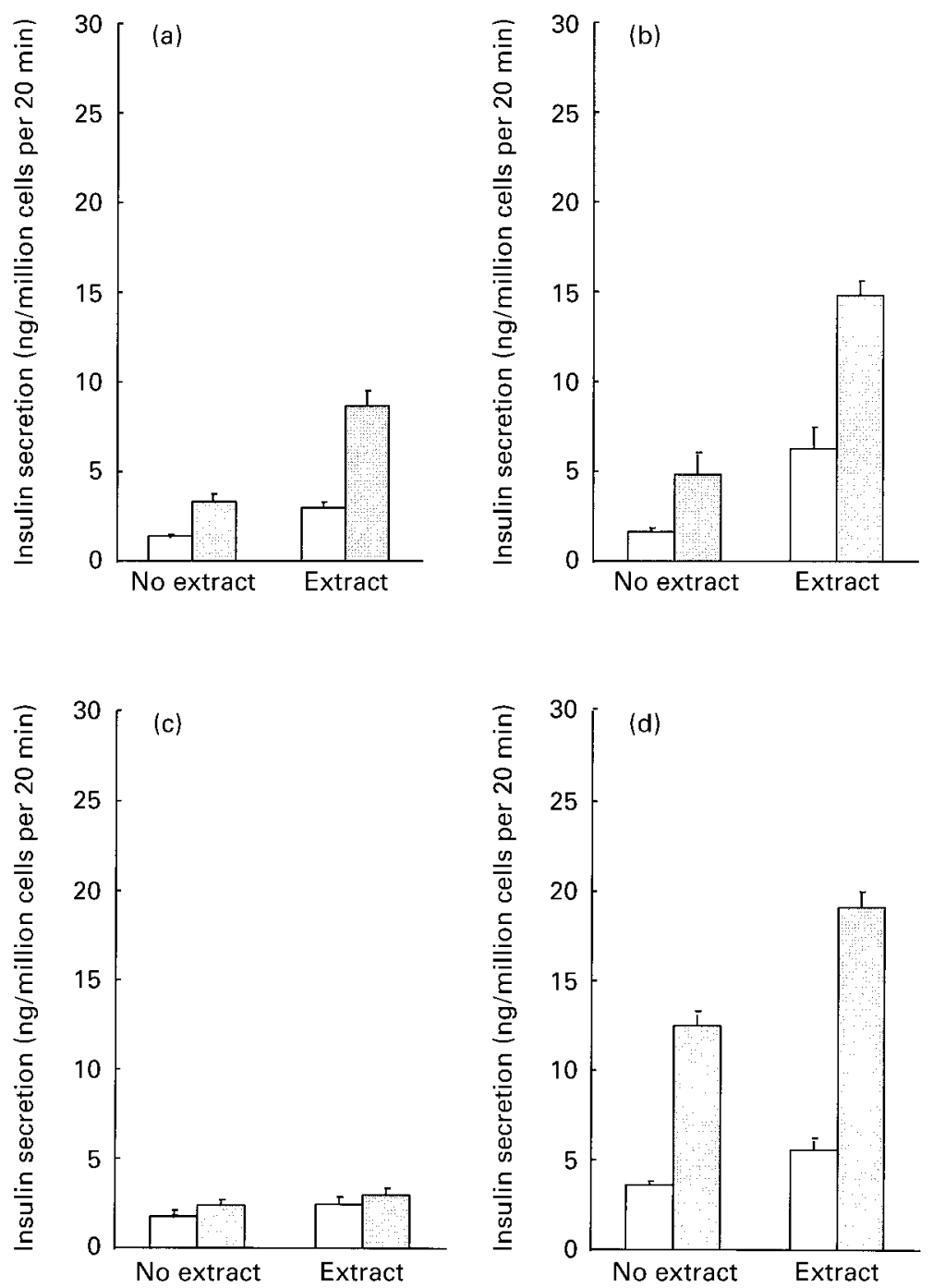

Fig. 3. Insulin secretion by BRIN-BD11 cells incubated in the presence or absence of aqueous coriander extract $(1 \mathrm{mg} / \mathrm{ml})$ with various other

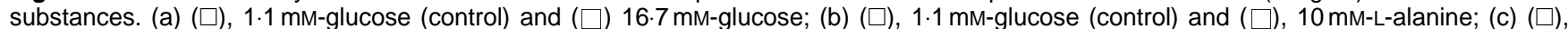
$1.1 \mathrm{mM}$-glucose (control) and ( $\square$ ), 1 mM-3-isobutyl-1-methylxanthine (IBMX); (d) ( $\square$ ), $16.7 \mathrm{mM}$-glucose (control) and ( $\square$ ), $25 \mathrm{mM}$-KCl. Values are means for groups of six observations with their standard errors indicated by vertical bars. Two-way ANOVA revealed: (a) extract effect $(P<$ $0.001)$, glucose effect $(P<0.001)$ and extract $\times$ glucose interaction $(P<0.004)$; (b) extract effect $(P<0.001)$, L-alanine effect $(P<0.001)$ and extract $\times \mathrm{L}$-alanine interaction $(P=0.021)$; (c) extract effect $(P<0.001)$ and IBMX effect $(P<0.001)$; (d) extract effect $(P<0.001)$, KCl effect $(P<0.001)$ and extract $\times \mathrm{KCl}$ interaction $(P=0.02)$.

sugar levels of normal and alloxan diabetic rats, but demonstrated alleviation of adrenaline-induced hyperglycaemia (Sharaf et al. 1963). Subsequent studies involving longerterm administration of coriander seed in the diet showed that the plant purported as a traditional treatment for diabetes indeed decreased the hyperglycaemia of STZ-diabetic mice (Swanston-Flatt et al. 1990). The present study not only confirms this antihyperglycaemic action but indicates the presence of natural products in coriander which exhibit insulin-releasing and insulin-like actions. The possibility also exists that dietary administration of coriander affords protection against STZ-induced pancreatic B-cell destruction, but this requires further evaluation.

The possibility that part of the glucose lowering action of coriander may be due to an effect on glucose handling by skeletal muscle was evaluated in vitro using an insulinsensitive mouse skeletal muscle preparation (Gray \& Flatt,
$1998 b$ ). These experiments revealed that an aqueous extract of coriander enhanced glucose transport, glucose oxidation and glycogenesis to an extent comparable with $10^{-8} \mathrm{M}$-insulin. The combined actions of coriander and insulin on muscle were not additive, suggesting that the active constituent(s) of coriander extract acts through a pathway similar in part to that utilized by insulin. Interestingly, the action of coriander differs significantly from that of the established antihyperglycaemic drug, metformin, which exerts effects on glucose transport via insulin-mediated peripheral glucose uptake (Bailey \& Puah, 1986; Prager et al. 1986).

Experiments using clonal pancreatic B-cells showed that coriander extract stimulated insulin secretion in a dosedependent fashion over the concentration range $0 \cdot 25$ $10 \mathrm{mg} / \mathrm{ml}$. The maximal fivefold insulin response can be compared with an approximate doubling of insulin release in this cell line induced by micromolar concentrations of 


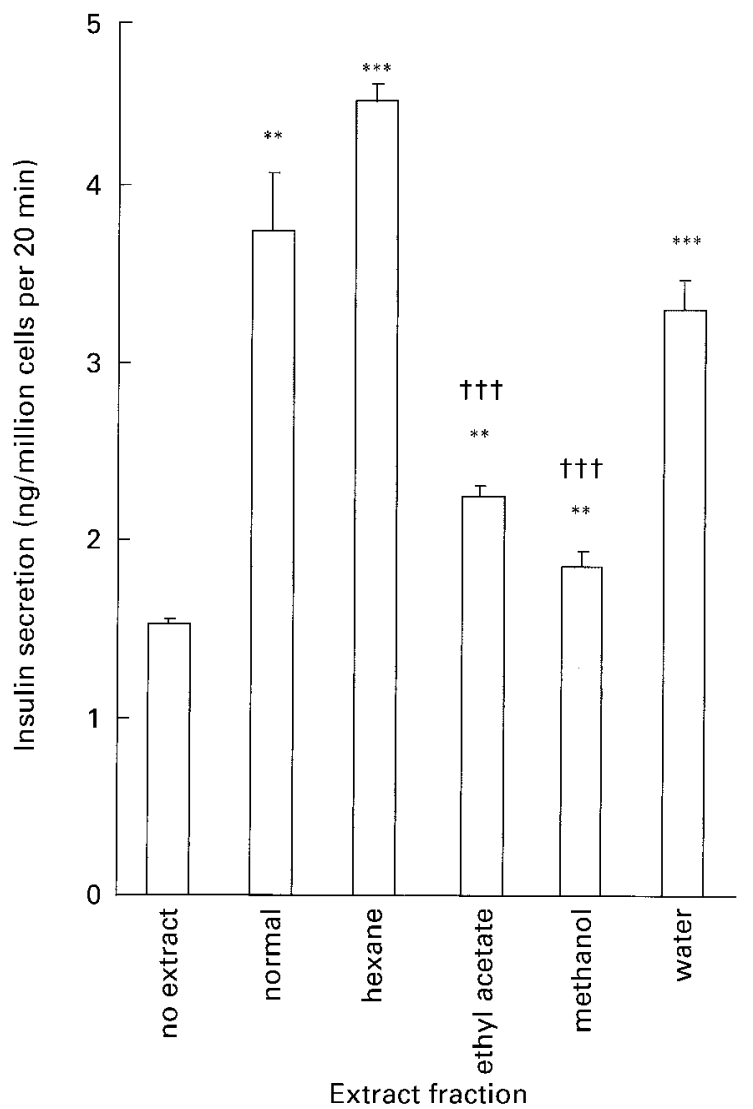

Fig. 4. Insulin secretion by BRIN-BD11 cells in response to extracts of coriander. Coriander was subjected to sequential extraction by solvents with increasing polarity; all extracts were tested at concentrations equivalent to $1 \mathrm{mg} / \mathrm{ml}$. Values are means for groups of six observations with their standard errors represented by vertical bars. Mean values were significantly different from those for incubations without extract: ${ }^{* *} P<0.01,{ }^{* * *} P<0.001$. Mean values were significantly different from those for incubations with normal extract (produced by $15 \mathrm{~min}$ decoction): $\uparrow \dagger \uparrow P<0.001$.

Table 3. Effect of heat, dialysis, acid-alkali treatment and acetone treatment on ability of aqueous extract of coriander to enhance insulin secretion by BRIN-BD11 cellsł

(Mean values with their standard errors for six observations)

\begin{tabular}{|c|c|c|}
\hline \multirow[b]{2}{*}{ Test } & \multicolumn{2}{|c|}{$\begin{array}{c}\text { Insulin secretion } \\
\text { (ng/10 cells per } 20 \mathrm{~min})\end{array}$} \\
\hline & Mean & SEM \\
\hline Control (without extract) & 1.57 & 0.06 \\
\hline Untreated extract & $2 \cdot 87^{\star \star *}$ & 0.16 \\
\hline Boiled extract & $2 \cdot 78^{\star \star}$ & 0.38 \\
\hline Dialysed extract & $2 \cdot 43^{* * *}$ & 0.16 \\
\hline Acid-exposed extract & $2 \cdot 36^{\star *}$ & 0.23 \\
\hline Alkali-exposed extract & $2 \cdot 08^{*} \dagger \dagger$ & 0.16 \\
\hline Acetone-insoluble extract & $1.44 \dagger+\dagger$ & 0.08 \\
\hline Acetone-soluble extract & $2 \cdot 76^{\star \star \star}$ & 0.16 \\
\hline
\end{tabular}

Mean values were significantly different from that for the control incubation: ${ }^{*} P$ $<0.05,{ }^{* \star} P<0.01,{ }^{\star * \star} P<0.001$

Mean values were significantly different from that for the untreated extract (produced by $15 \mathrm{~min}$ decoction): $\uparrow \dagger P<0.01, \dagger_{\dagger} P<0.001$.

$\ddagger$ Normal extract was subject to heat, overnight dialysis, acid-alkali or acetone treatment. For details of procedures, see pp. 203-205. sulfonylureas, tolbutamide and glibenclamide (McClenaghan et al. 1998; McClenaghan \& Flatt, 1998). The stimulatory action of coriander extract was also glucosedependent and potentiated by the established amino acid stimulator L-alanine. However, insulin release was not enhanced by the phosphodiesterase inhibitor 3-isobutyl-1methylxanthine which increases cyclic AMP and enhances hormone-mediated insulin release (Sharp, 1979). Importantly, prior exposure to $0.5 \mathrm{mg} / \mathrm{ml}$ extract did not diminish the subsequent insulin secretory response to L-alanine, thereby negating a possible deleterious effect of extract on cell viability in the insulin secretion experiments. The nontoxic nature of coriander extract was also confirmed by toxicity testing using the modified neutral red assay.

Studies performed to evaluate further the possible mechanisms underlying the insulin-releasing action of coriander extract confirmed an action similar to that of sulfonylureas. These agents act by binding to sulfonylurea receptors, resulting in closure of plasma membrane $\mathrm{K}^{+}$-ATP channels, membrane depolarization, opening of voltagedependent $\mathrm{Ca}$ channels and elevation of intracellular $\mathrm{Ca}^{2+}$ (Rorsman, 1997). Diazoxide, by holding open $\mathrm{K}^{+}$-ATP channels, inhibits the stimulatory action of sulfonylureas (Dunne et al. 1994). In the present study, diazoxide also inhibited the insulin-releasing action of coriander. Like sulfonylureas (Flatt et al. 1994; Eliasson et al. 1996) coriander also stimulated insulin release from chemically depolarized cells incubated with $25 \mathrm{mM}-\mathrm{KCl}$. This suggests that constituents of coriander extract have $\mathrm{K}^{+}$-ATP channel and distal actions similar to sulfonylureas. However, the greater potency of coriander extract compared with maximally effective concentrations of sulfonylureas suggests possible additional actions on B-cell nutrient metabolism or secondmessenger pathways.

Preliminary investigations into the nature of the insulinreleasing agent(s) in coriander indicate heat stability, acetone solubility and resistance to acidic or alkaline environments. Extract activity was not due to smaller molecules or ions as suggested by retention of potency following dialysis to remove components of low molecular mass $(<2000 \mathrm{Da})$. Studies using sequential solvent extractions of coriander seeds point towards cumulative insulin-releasing effects of more than one active constituent of coriander. The involvement of these or other extract components in mediating the effects of coriander on glucose uptake and metabolism clearly merit further investigation.

In conclusion, the present study has shown that the antihyperglycaemic action of coriander is associated with stimulation of insulin secretion and enhancement of glucose uptake and metabolism by muscle, reflecting the effects of more than one active constituent. Coriandrum sativum therefore represents a possible antihyperglycaemic dietary adjunct and potential source of a new orally active agent(s) for diabetes therapy.

\section{Acknowledgements}

These studies were supported by the Department of Health and Social Services, Northern Ireland and NI Developmental Research funding. 


\section{References}

Bailey CJ \& Day C (1989) Traditional plant medicines as treatments for diabetes. Diabetes Care 12, 553-564.

Bailey CJ \& Flatt PR (editors) (1990) New Antidiabetic Drugs, pp. 1-295. London: Smith-Gordon.

Bailey CJ \& Puah JA (1986) Effect of metformin on glucose metabolism in mouse soleus muscle. Diabète et Metabolisme 12, 212-218.

Dunne MJ, Harding EA, Jaggar JH, Ayton BJ \& Squires PE (1994) Endogenous and chemical activators of ATP-regulated potassium channels in insulin-secreting cells: possible mechanisms and physiological significance. In Frontiers of Insulin Secretion and Pancreatic B-Cell Research, pp. 153-159 [PR Flatt and S Lenzen, editors]. London: Smith-Gordon.

Eliasson L, Renström E, Ämmälä C, Berggren P-O, Bertorello AM, Bokvist K, Chibalin A, Deeney JT, Flatt PR, Gabel J, Gromada J, Larsson O, Lindström P, Rhodes CJ \& Rorsman P (1996) PKC-Dependent stimulation of exocytosis by sulfonylureas in pancreatic B-cells. Science 271, 813-815.

Farnsworth NR \& Segelman AB (1971) Hypoglycaemic plants. Tile and Till 57, 52-55.

Flatt PR \& Bailey CJ (1981) Abnormal plasma glucose and insulin responses in heterozygous lean $(o b /+)$ mice. Diabetologia 20 , 573-577.

Flatt PR, Shibier O, Szecowka J \& Berggren P-O (1994) New perspectives on the actions of sulphonylureas and hyperglycaemic sulphonamides on the pancreatic B-cell. Diabète et Metabolisme 20, 157-162.

Gray AM \& Flatt PR (1997a) Nature's own pharmacy: the diabetes perspective. Proceedings of the Nutrition Society 56, 507-517.

Gray AM \& Flatt PR (1997b) Pancreatic and extra-pancreatic effects of the traditional anti-diabetic plant, Medicago sativa (lucerne). British Journal of Nutrition 78, 325-334.

Gray AM \& Flatt PR (1998a) Actions of the traditional antidiabetic plant, Agrimony eupatoria (agrimony): effects on hyperglycaemia, cellular glucose metabolism and insulin secretion. British Journal of Nutrition 80, 109-114.

Gray AM \& Flatt PR (1998b) Insulin-releasing and insulin-like activity of Agaricus campestris (mushroom). Journal of Endocrinology 157, 259-266.
Hunt SM, Chrzanowska C, Barnett CR, Brand HN \& Fawell JK (1987) A comparison of in vitro cytotoxicity assays and their application to water samples. Alternatives to Laboratory Animals 15, 20-29.

Lewis WH \& Elvin-Lewis MPF (1977) Medical Botany: Plants Affecting Man's Health. New York, NY: Wiley.

Lust J (1986) The Herb Book. London: Bantam Books.

McClenaghan NH, Barnet CR, Ah-Sing E, Abdelwahab YHA, O'Harte FPM, Yoon T-W, Swanston-Flatt SK \& Flatt PR (1996) Characterization of a novel glucose-responsive insulin-secreting cell line, BRIN-BD11, produced by electrofusion. Diabetes $\mathbf{4 5}$, 1132-1140.

McClenaghan NH \& Flatt PR (1998) Engineering cultured insulinsecreting pancreatic B-cell lines. Journal of Molecular Medicine (In the Press).

McClenaghan NH, Flatt PR \& Bailey CJ (1998) Insulin-releasing action of the novel antidiabetic agent BTS 67 582. British Journal of Pharmacology 123, 400-404.

Prager R, Schernthaser G \& Graf H (1986) Effect of metformin on peripheral insulin sensitivity in non-insulin dependent diabetes mellitus. Diabète et Metabolisme 12, 346-350.

Rorsman P (1997) The pancreatic B-cell as a fuel sensor: an electrophysiologist's view point. Diabetologia 40, 487-495.

Sharaf AA, Hussein AM \& Mansour MY (1963) Studies on the antidiabetic effects of some plants. Planta Medica 11, 159-168.

Sharp GWG (1979) The adenylate cyclase-cyclic AMP system in islets of Langerhans and its role in the control of insulin release. Diabetologia 16, 287-297.

Stevens JF (1971) Determination of glucose by automatic analyser. Clinica Chimica Acta 32, 199-201.

Swanston-Flatt SK, Day C, Bailey CJ \& Flatt PR (1990) Traditional plant treatments for diabetes: studies in normal and streptozotocin diabetic mice. Diabetologia 33, 462-464.

Swanston-Flatt SK, Flatt PR, Day C \& Bailey CJ (1991) Traditional dietary adjuncts for the treatment of diabetes mellitus. Proceedings of the Nutrition Society 50, 641-651.

World Health Organization (1980) World Health Organization Expert Committee on Diabetes Mellitus, Second Report. Technical Report Series no. 646, p. 66. Geneva: WHO. 


\section{A leading international journal publishing authoritative, timely and in-depth reviews...}

\section{Nutrition}

Research Reviews

General Editor JM Forbes (UK)

Editors

JDJ Millward (UK)

HJ Powers (UK)

DI Thurnham (UK)

PYaqoob (UK)

International Editors

J Black (Australia)

L Hambraeus (Sweden)

JOkumura (Japan)

NW Solomons (Guatemala)

CM Weaver (USA)

\section{(11) $\mathrm{CABI}$ Publishing}

publishes Nutrition Research Reviews on behalf of The Nutrition Society
Contributions by international experts:

- advance new concepts

- encourage fresh thinking

- highlight timely reports on important techniques and methods in experimental work

- provide thorough overviews on specific subject areas

- promote scientific communications on new ideas

Reviews of large-scale, international projects and surveys such as the EURESTA project feature prominently in Nutrition Research Reviews.

Leading nutritionists look back on a lifetime of involvement in important developments in nutrition research.

Forthcoming papers include:

- Homocysteine as a risk factor for cardiovascular and related disease: nutritional implications

- Irritable bowel syndrome: the interactions of diet and stress

- Perspectives on ruminant nutrition and metabolism

- Lipids and infant formulas

1999, Volume 12

Bi-annual publication (June and December)

ISSN: 09544224

$£ 100.00$ (US $\$ 180.00$ Americas only)

To order your 1999 subscription to this important journal contact:

CABI Publishing

$\mathrm{CAB}$ International

Wallingford, Oxon, OX10 8DE, UK

Tel: +44 (0) 1491832111

Fax: +44 (0) 1491829292

Email: publishing@cabi.org

CABI Publishing

$\mathrm{CAB}$ International

10 East 40th Street, Suite 3203,

New York, NY 10016, USA

Tel: +1 (212) 4817018

Toll-free: 18005284841

Fax: +1 (212) 6867993

Email: cabi-nao@cabi.org 